\title{
Testis Sparing Surgery in Children
}

\author{
Çocuklarda Testis Koruyucu Cerrahi
}

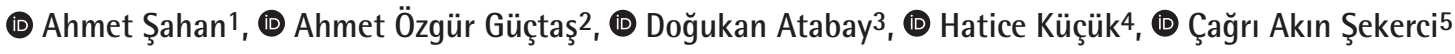 \\ 1 Lütfi Kırdar Kartal Training and Research Hospital, Clinic of Urology, İstanbul, Turkiye \\ 2Trabzon Kanuni Training and Research Hospital, Clinic of Urology, Trabzon, Turkiye \\ 3Trabzon Kanuni Training and Research Hospital, Clinic of Radiology, Trabzon, Turkiye \\ 4 Trabzon Kanuni Training and Research Hospital, Clinic of Pathology, Trabzon, Turkiye \\ 5Trabzon Kanuni Training and Research Hospital, Clinic of Pediatric Urology, Trabzon, Turkiye
}

\begin{abstract}
Although the standard treatment for testicular tumors is radical orchiectomy in children, testis-sparing surgery (TSS) is an alternative method in selected cases according to tumor size, tumor markers and histopathological findings. In this paper, we present two patients aged 11 and 12 years who underwent TSS in our clinic. Frozen section examination was performed in both patients. Intraoperative ultrasound-guided mass excision was performed in one patient. Histopathological examination revealed an epidermoid cyst in one patient and Leydig cell hyperplasia in the other. TSS may be performed in children with a small testicular mass and negative tumor markers.
\end{abstract}

Keywords: Child, Testicular tumors, Minimally invasive surgical procedures

Öz

Çocuklarda testis tümörünün standart tedavisi radikal orşiektomi olmasına rağmen tümör boyutları, belirteçleri ve histopatolojik bulgulara göre uygun olgularda testis koruyucu cerrahi (TKC) alternatif bir yöntemdir. Bu olgu sunumunda yaşları 11 ve 12 olan TKC uygulanan iki hastanın sunulması amaçlanmıştır. İki hastada da frozen incelemesi yapılmıştır. Bir hastada peroperatif ultrasonografi eşliğinde kitle eksizyonu yapılmıştır. Histopatolojik incelemede bir hastada epidermoid kist ve diğer hastada leydig hücre hiperplazisi olarak raporlanmıştır. Testis koruyucu cerrahi küçük testis kitlesi ve negatif tümör belirteçleri olan çocuklarda uygulanabilir.

Anahtar Kelimeler: Çocuk, Testis Tümörü, Minimal İnvaziv Cerrahi Yöntemler

\section{Introduction}

The majority of testicular masses in children are benign. Characteristics of testicular masses cannot be fully evaluated by imaging methods such as ultrasound (US) and magnetic resonance imaging (MRI). Small size and cystic characteristics increase the likelihood of a mass having a benign etiology. Radical orchiectomy is the gold standard of treatment for childhood testicular tumors. Testis-sparing surgery (TSS) is one of the methods that can be used to prevent loss of organ due to surgery and overtreatment in selected patients with benign masses. In this article, we aimed to share our experience in TSS in children.

\section{Case Presentations}

\section{Case 1}

An 11-year-old male patient presented with the complaint of inguinal pain. Physical examination revealed a left testicular mass measuring approximately $5 \mathrm{~mm}$ in diameter. Development of external genitalia and pubic hair were Tanner stage 2. Scrotal Doppler US revealed a solid mass in the left testis $5.5 \mathrm{~mm}$ in diameter with central anechoic area. Tumor markers were normal. A $6 \mathrm{~mm}$ mass inferior to the left testis was detected on MRI. TSS was planned. Under general anesthesia, the testis and spermatic cord were released with inguinal incision. The testicular mass

Correspondence: Çağıı Akın Şekerci MD, Trabzon Kanuni Training and Research Hospital, Clinic of Pediatric Urology, Trabzon, Turkiye E-mail: dr.hatice.kucuk@hotmail.com ORCID-ID: orcid.org/0000-0002-0334-2466 Received: 03.01.2019 Accepted: 26.03.2019

Cite this article as: Şahan A., Güçtaş AÖ, Atabay D, Küçük H, Şekerci ÇA. Testis Sparing Surgery in Children. J Urol Surg 2019;6(3):255-257.

๑Copyright 2019 by the Association of Urological Surgery / Journal of Urological Surgery published by Galenos Publishing House. 
was excised after the spermatic cord was clamped with bulldog clips. Frozen section examination revealed a $7 \mathrm{~mm}$ keratinous cyst. The testis was placed in the scrotum and the operation was terminated (Figure 1). Postoperative follow-up was uneventful. Pathological diagnosis was epidermoid cyst.

\section{Case 2}

A 12-year-old male patient was admitted to our clinic due to trauma that occurred during sports. He had a history of hormone therapy due to left undescended testis at the age 1.5 years. Physical examination was normal. Development of external genitalia and pubic hair were Tanner stage 2. A scrotal Doppler US revealed a $2.5 \times 4 \mathrm{~mm}$ hyperechoic mass in the left testis. Tumor markers were normal (Beta-hCG $<0.5$ $\mathrm{mIU} / \mathrm{mL}$, AFP: $1.06 \mathrm{ng} / \mathrm{mL}$ ). MRI showed a $4 \mathrm{~mm}$ focal area with intratesticular contrast enhancement in the left testis. TSS was planned. Intraoperative US was used to locate the mass and a $4 \mathrm{~mm}$ mass in the left testis was excised (Figure 2). Frozen section examination revealed a $4 \mathrm{~mm}$ Leyding cell hyperplasia. Postoperative follow-up was uneventful. Pathological diagnosis was Leyding cell hyperplasia (Figure 3).

\section{Discussion}

Testicular tumors are very rare in children. Testicular tumors account for $1-2 \%$ of all solid tumors in children and $3 \%$ of all testicular tumors. The incidence of testicular tumor is approximately 0.5-2 per 100.000 children and adolescents (1). In past years, most testicular tumors in children were thought to be malignant. However, in recent years, it has been shown that benign lesions, especially teratomas, were more common $(2,3)$.
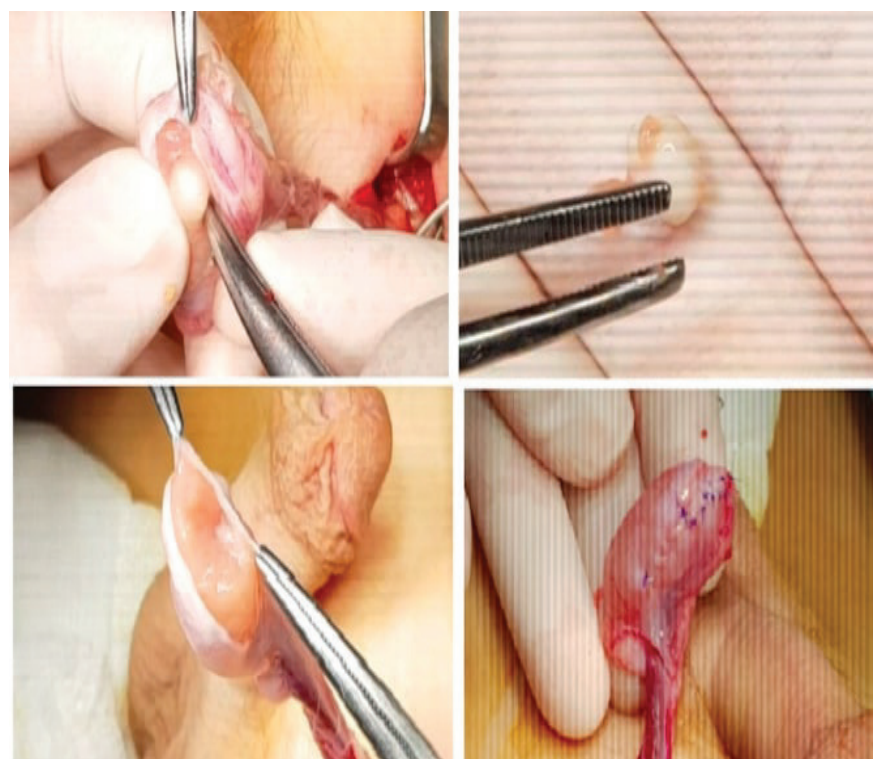

Figure 1. Testis Sparing Surgery. Enucleation of testis mass, testis mass, excision area, closure of tunika albuginea
According to the German Cancer Study Group, TSS is only recommended in patients with a mass in solitary testis or patients with bilateral tumors of less than $2 \mathrm{~cm}$, no rete testis invasion and normal preoperative luteinizing hormone levels. The European Association of Urology Guidelines recommends TSS for synchronous bilateral tumors, metachronous contralateral tumors or normal preoperative testosterone levels and solitary testis with a tumor volume of less than $30 \%$ of the testicular volume. Intraoperative US and frozen examinations can provide information about the character of the mass in the testis, allowing prevention of recurrences (4).

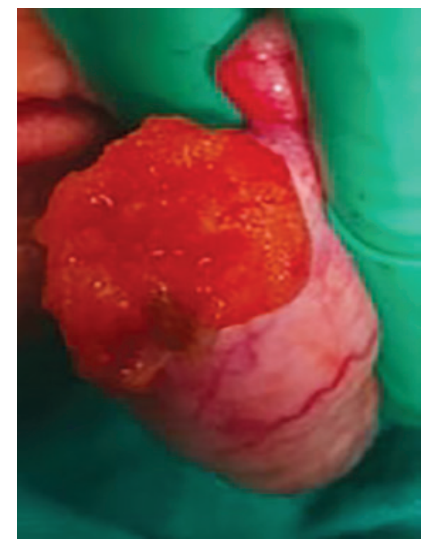

Figure 2. Leydig cell hyperplasia

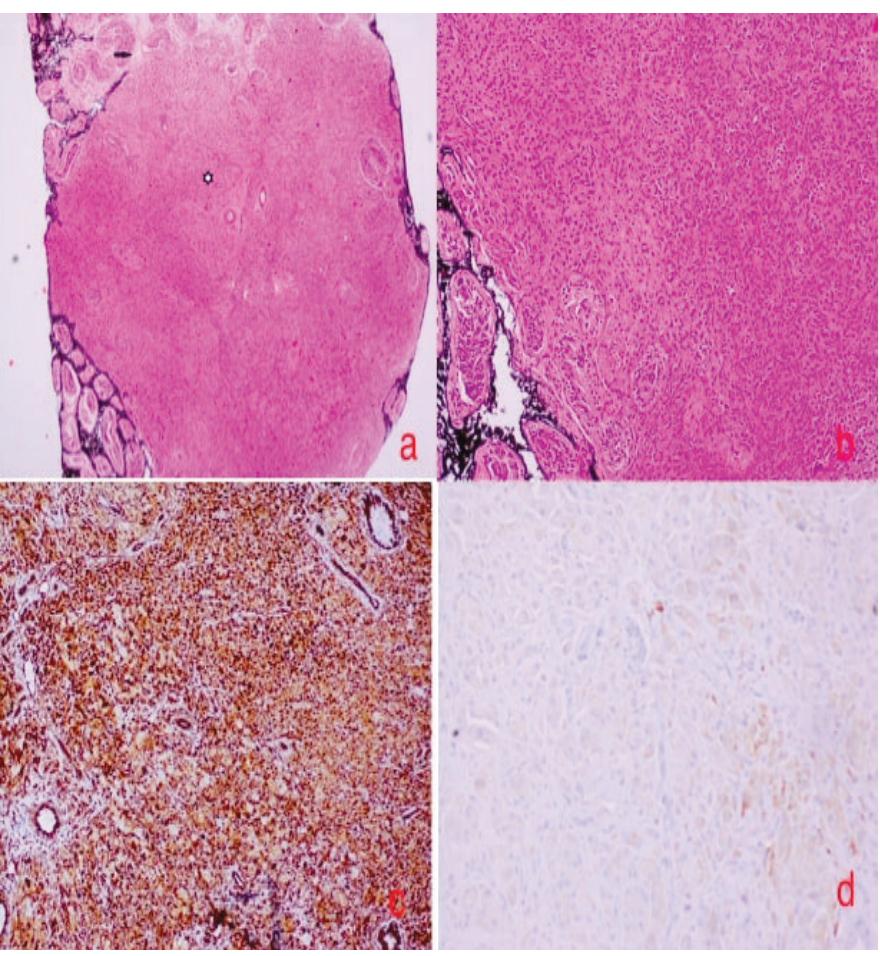

Figure 3. Pathological images of leydig cell hyperplasia: a) HEX10, arrow shows the normal tubule structure, star leydig cells. This picture shows normal tubule structure and non-destructive leydig cell hyperplasia. b) HEX20. c) VimentinX20 (immunohistochemical staining, Vimentin +). d) Inhibin X20 (Immunohistochemical staining, Inhibin weak +) 
Organ-sparing surgery has begun to replace radical orchiectomy in childhood testicular tumors. The most important reason for this is the fact that most testicular tumors are benign in childhood. Teratoma, epidermoid cysts and stromal tumors constitute two-thirds of testicular tumors in children under 12 years of age. Yolk sac tumors account for less than 15\% of pediatric testicular tumors. The organ-sparing approach is recommended in children with normal tumor markers, benign US findings and intraoperative frozen section (5).

In the case series of Emre et al. (6) , 4 patients underwent TSS, 3 patients had Leyding cell hyperplasia and 1 patient had a Leyding cell tumor. None of the patients had recurrence and testicular atrophy. In one patient, contralateral metachronous lesion was detected and treated successfully. This suggests that orchiectomy should not be performed in benign lesions (6). In a study by Friend et al. (7), TSS was recommended as standard treatment for epidermoid cysts, however, it was not recommended for follow-up of patients with testicular epidermoid cyst. In one case, orchiectomy was performed because of the fact that distinguishing malignant from benign tumor could not be made in frozen examination (7). In their study, Bujons et al. (8) reported that 15 children in pre-pubertal period underwent TSS and 4 patients had epidermoid cysts. There was no recurrence, metastasis or testicular atrophy.

In a study by Mennie et al. (9), TSS was performed in 3 patients with Leyding cell hyperplasia, two of whom were diagnosed incidentally. No recurrence was observed in follow-up. Testicular tumors in children with normal biochemical markers without findings of precocious puberty can be followed by US and unnecessary surgeries are prevented. However, if the lesions do not regress in follow-up, excisional biopsy and frozen section examination may be necessary (9).

It is thought that the remaining testis may provide normal hormonal and reproductive functions after unilateral orchiectomy. However, some studies have shown that loss of testicular tissue is related to infertility, endocrine deficiencies and sexual and psychological problems $(10,11,12)$. In a study by Heidenreich et al. (13), 84 of 101 patients treated with TSS for germ cell tumors showed normal postoperative testosterone levels. Ten patients had hypogonadism and received androgen supplementation postoperatively and 6 remained on preoperative hypogonadism. To prevent irreversible damage, a warm ischemia time not exceeding 30 minutes is recommended during TSS (14). It has been reported that fertility is maintained in 50\% of patients with intraepithelial neoplasia and normal testosterone levels (15).

In conclusion, testis-sparing procedure may be performed in children with a small testicular mass and negative tumor markers. To prevent recurrence, the lesion should be completely excised. If necessary, radical orchiectomy should be performed.

\section{Ethics}

Informed Consent: Written consent from the parents before.

Peer-review: Externally peer-reviewed.

\section{Authorship Contributions}

Concept: A.Ş., C..A.Ş., Design: A.Ş., Ç.A.Ş., Data Collection and/ or Processing: A.Ş., Ç.A.Ş., Analysis and/or Interpretation: A.Ş., A.Ö.G., Ç.A.Ş., D.A., H.K., Literature Research: A.Ş., A.Ö.G., Ç.A.Ş., Writing: A.Ş., A.Ö.G., Ç.A.Ş.

Conflict of Interest: No conflict of interest was declared by the authors.

Financial Disclosure: The authors declared that this study received no financial support.

\section{References}

1. Kay R. Prepubertal testicular tumor registry. J Urol 1993;150:671-4.

2. Bujons A, Sfulcini JC, Pascual M, Feu OA, Garat JM, Villavicencio $H$. Prepubertal testicular tumours and efficacy of testicular preserving surgery. BJU Int 2011;107:1812-1816.

3. Taskinen S, Fagerholm R, Aronniemi J, Rintala R, Taskinen M. Testicular tumors in children and adolescents. J Pediatr Urol 2008;4:134-137.

4. Borghesi M, Brunocilla E, Schiavina R, Gentile G, Dababneh H, Della Mora $\mathrm{L}$, et al. Role of testis-sparing surgery in the conservative management of small testicular masses: Oncological and functional perspectives. Actas Urol Esp 2015;39:57-62.

5. Djaladat H. Organ-sparing surgery for testicular tumours. Curr Opin Urol. 2015;25:116-120.

6. Emre S, Ozcan R, Elicevik M, Emir H, Soylet Y, Buyukunal C. Testis sparing surgery for Leydig cell pathologies in children. J Pediatr Urol 2017;13:51. e1-51.e4.

7. Friend J, Barker A, Khosa J, Samnakay N. Benign scrotal masses in children - some new lessons learned. J Pediatr Surg 2016;51:1737-1742.

8. Bujons A, Sfulcini JC, Pascual M, Feu OA, Garat JM, Villavicencio H. Prepubertal testicular tumours and efficacy of testicular preserving surgery. BJU Int 2011;107:1812-1816.

9. Mennie N, King SK, Marulaiah M, Ferguson P, Heloury Y, Kimber C. Leydig cell hyperplasia in children: Case series and review. J Pediatr Urol 2017;13:158163.

10. Huddart RA, Norman A, Moynihan C, Horwich A, Parker C, Nicholls E, et al. Fertility, gonadal and sexual function in survivors of testicular cancer. $\mathrm{Br} J$ Cancer 2005;93:200-207.

11. Ferreira U, Netto Júnior NR, Esteves SC, Rivero MA, Schirren C. Comparative study of the fertility potential of men with only one testis. Scand J Urol Nephrol 1991;25:255-259.

12. Arai $Y$, Kawakita $M, O$ kada $Y$, Yoshida 0 . Sexuality and fertility in long-term survivors of testicular cancer. J Clin Oncol 1997;15:1444-1448.

13. Heidenreich $A$, Albers $P$, Krege $S$. Management of bilateral testicular germ cell tumours-experience of the German testicular cancer study group (GTCSG). J European Urology Supplements 2006;5:97.

14. Miller DC, Peron SE, Keck RW, Kropp KA. Effects of hypothermia on testicular ischemia. J Urol 1990;143:1046-1048.

15. Catanzaro M, Piva L, Torelli T, Biasoni D, Stagni S, Milani A, et al. Funcion sparing surgery in uro-oncology: germ cell tumors of the testis. Urologia 2012;79:15-19. 